\title{
景観計画における概念的な定義を用いた眺望景観保全制度に関する研究 A STUDY ON THE ADMINISTRATIVE SYSTEM OF VIEW PROTECTION
WITH CONCEPTUAL DEFINITION OF LANDSCAPE PLAN
}

\author{
浅野 聡*1, 上田拓矢 ${ }^{* 2}$, 水野芳彦*3 \\ Satoshi ASANO, Takuya UEDA and Yoshihiko MIZUNO
}

\begin{abstract}
The purpose of this study is to clarify the characteristic, the reason for institution and the issue of view protection with conceptual definition. The questionnaire survey to landscape administrative organization was conducted by authors. Through analysis of survey results, four components of system of view protection; view target, viewpoint, view protection district, view protection standard were classified and clarified. There is no serious issue of system of view protection. However, it is desirable for that system to become a practicable approach with a concrete definition rather than a conceptual definition.
\end{abstract}

Keywords : Landscape Law, Landscape Plan, View, System of View Protection 景観法，景観計画，眺望景観，眺望景観保全制度

1.はじめに

\section{(1) 研究の背景}

平成 16 年に景観法が制定されて以来、景観計画を策定して景観行 政に取り組む景観行政団体（以下、「団体」と略すことがある）が全 国的に増えてきている注 1)。近年の新しい景観行政の動きの 1 つと して、広域景観の保全・形成一の社会的な関心の高まり等を背景に、 眺望景観保全に取り組み始める団体が増えていることがあげられる。 京都市は「京都市眺望景観創生条例」を制定して積極的に取り組ん でおり、ここでは世界遺産に登録されている二条城等の重要な視対 象に対して、視点場や眺望景観保全基準が具体的に定められた上で、 眺望景観保全地区が指定されている注 2)。このように眺望景観保全 のためには、基本的には、視対象、視点場、眺望景観保全基準、眺 望景観保全地区等を具体的に定める必要があるが、眺望景観保全制 度は景観法において制度化されていなく各団体の独自の制度として 運用されていることから、眺望景観保全に対寸る記述や基準は様々 である。例えば、山並みへの良好な眺望景観を守り・育てるといっ た方針は示されていても、視対象や視点場等が具体的に示されてい ない景観計画も存在しており、これでは関係者（土地所有者、事業 者、地域住民、行政担当者等）が明確に内容を共有出来ず、行政担 当者による事業者等との協議や指導が不調におわり、眺望景観を阻 害する事例が生じることが危惧される。景観法の制定前の地方公共 団体による自主条例（景観条例）にもとづく景観行政は、いざとい
うときに具体的な強制力がないといった限界があり、各地でたびた

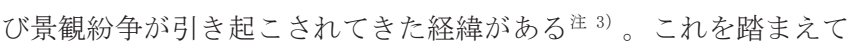
景観法は、景観計画区域内の行為に規制をかけるとともに、強制力 を伴う法的規制の枠組みとして勧告や変更命令を出すことが可能で あり注 4)、そのために国の景観法運用指針では、景観計画は全体的 に明示的、具体的に表示寸るという方針が示されている注5)。

以上のように実行力のある眺望景観保全を推し進めていくために は、具体的な計画内容とすることが必要と考えられる。

(2) 研究の目的

本研究は、景観計画において概念的な定義を用いて設定、運用さ れている眺望景観保全制度（後述）を対象として、同制度を構成し ている視対象、視点場、眺望景観保全地区、眺望景観保全基準を類 型化してその特徵を明らかにするとともに、景観行政団体へのアン ケート調查を通じて、概念的な定義を用いた眺望景観保全制度の設 定の理由と現状の問題を明らかにすることを目的とする。

\section{(3) 用語の定義}

本研究における主要な用語の定義は、以下の通りである。各用語 の類型化と細類型化については、第 3 章で説明する。

\section{(1)視対象}

「視対象」とは、意識的に眺めることのできる眺望景観を構成し ている対象のことである。後述の通り、「具体型」、「概念型」、「不在 型」に類型化することができ、さらに「自然・ランドマーク型」「人

\footnotetext{
*1 三重大学大学院工学研究科 准教授・博士 (工学)

*2 三重大学大学院工学研究科 博士前期課程

*3 岡崎市建築部建築指導課 修士 (工学)

Assoc. Prof., Graduate School of Eng., Mie Univ., Dr.Eng. 
エ・ランドマーク型」「自然・パノラマ型」「人工・パノラマ型」、 「混合・パノラマ型」に細類型化することができる。

\section{(2)視点場}

「視点場」とは、対象とする眺望景観を眺めることのできる特定 の場所のことである。後述の通り、「具体型」、「概念型」、「不在型」 に類型化することができ、さらに「点型」、「線型」、「面型」に細類 型化することができる。

\section{(3)眺望景観保全地区}

「眺望景観保全地区」（以下、「眺望地区」あるいは単に眺望地区 数を指すときは「地区」と略すことがある）とは、眺望景観保全を 目的として設定されている地区のことである。後述の通り、「具体型」 「概念型」、「不在型」に類型化することができる。

\section{(4)眺望景観保全基準}

「眺望景観保全基準」（以下、「保全基準」と略すことがある）と は、眺望地区を対象に、眺望景観保全を目的として設定されている 建築物・工作物等の高さや規模、色彩等の基準（景観形成基準）の ことである。なお、眺望景観では、「高さ」をめぐる問題が紛争の要 因の 1 つとして指摘されている注 6) ことから、本研究では、特に眺 望景観保全に大きな影響を与える高さ基準を取りあげることとし、 それ以外については対象外とする。後述の通り、「具体型」として「高 さ基準 (定量)」、「概念型」として「高さ基準（定性）」、「不在型」 として「高さ基準なし」に類型化することができる。

\section{(5)眺望景観保全制度}

「眺望景観保全制度」とは、眺望景観保全を目的として、基本的 に「視対象」、「視点場」、眺望景観保全地区」、「眺望景観保全基準」 の 4 つの要素から構成されている制度とする。

\section{(6)概念的な眺望景観保全制度}

「概念的な眺望景観保全制度」とは、同制度を構成する「視対象」、 「視点場」、「眺望景観保全地区」、「眺望景観保全基準」の何れか 1 つ以上が、具体的ではなく概念的な定義となっているものとする。 例えば視対象や視点場においては、その名称、位置、範囲が景観計 画の中の文章及び地図上に明確に記載されていないものである。一 方、具体的な定義とは、これらが全て明確に記載されているもので ある。本研究における眺望景観保全制度の具体的な定義と概念的な 定義をまとめると、Table1 に示す通りである。また、視対象と視点 場の細類型の定義を Table2 に示す。

\section{(4) 既往研究における本研究の位置付け}

景観計画における眺望景観保全に着目した既往研究としては、岡 村（2009）注 7)、川崎（2010）注 8)、大澤（2014）注 9）等がある。岡 村は、眺望景観保全の取り組みにおける計画の立案及び運用実態を 把握するため、視点場の指定とその誘導範囲の設定に着目して眺望 景観保全制度を類型化し、各類型の概要及びそれらの相互関係を明 らかにしている。川崎は、眺望景観保全を目的とした建築物等の高 さ制限手法と運用課題を明らかにするために、景観行政団体によっ て高さ制限の政策手法が導入された背景となる地域の特徴や運用の 相関を比較分析し、大澤は、建築物等の高さ制限と課題を明らかに するために高さ制限の活用事例を調査し、その意義や役割、制限実 施にあたっての留意点を提示している。

以上のような既往研究はあるものの、概念的な定義を用いた眺望 景観保全制度を主な対象とするものは不在である。本研究では、そ
Table1 Outline of view protection system regarding （概念的な定義を持つ眺望景観保全制度）

\begin{tabular}{|c|c|c|c|c|c|}
\hline \multicolumn{2}{|c|}{$\begin{array}{l}\text { View protection system } \\
\text { (䀝䍿憘観保全制度) }\end{array}$} & $\begin{array}{c}\text { View target } \\
\text { (視对象) }\end{array}$ & $\begin{array}{l}\text { Viewpoint } \\
\text { (䘽点埸) }\end{array}$ & \begin{tabular}{|c} 
View protection \\
district \\
(鮡垃地区)
\end{tabular} & \multirow{2}{*}{ 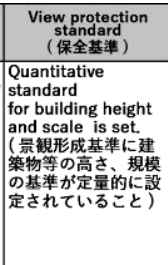 } \\
\hline 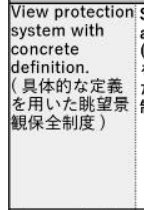 & $\begin{array}{l}\text { Satisfy the } \\
\text { all condition. } \\
\text { (右記の条件 } \\
\text { をすでて満 } \\
\text { たしている } \\
\text { 制度) }\end{array}$ & 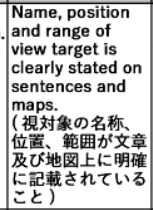 & 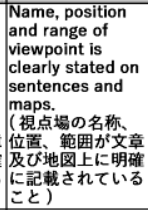 & 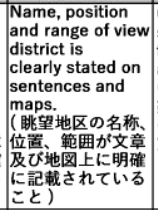 & \\
\hline 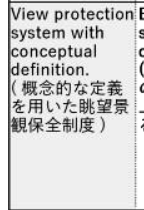 & 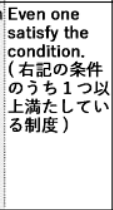 & 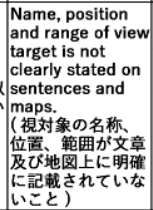 & 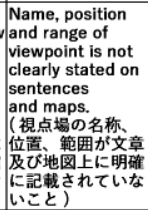 & 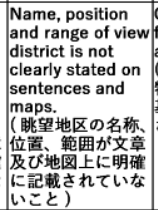 & 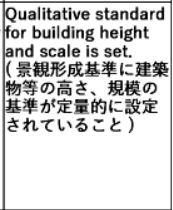 \\
\hline
\end{tabular}

Table2 Subclassification of view target and viewpoint (視対象および視点場の細類型)

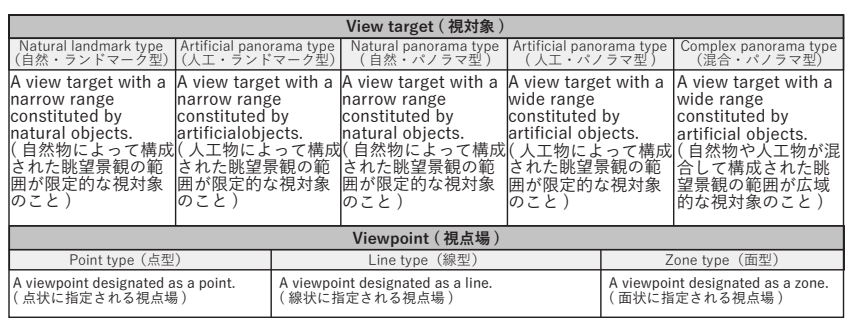

の実態として、制度内容の詳細、概念型になる傾向が高い要因、概 念型とした理由、現状の問題等を明らかにしており、第 5 章にて論 じる通り、概念型を見直す意向のある団体が一定数ある中で、具体 型へと見直寸際に本研究の成果を活用寸ることが可能であり、この 点において新規性や有用性があると考えられる。

\section{2.研究の方法}

\section{(1) 研究の対象}

研究対象の選定方法としては、まず、国土交通省ホームページに おける「景観計画の策定状況」（平成 27 年 10 月 1 日現在）注 ${ }^{10 ） を ~}$ 参照して、平成 27 年 10 月 1 日までに景観計画を策定した 664 団体 を選定し、当該団体の景観計画をホームページからダウンロードし て収集した。ホームページ上で公開されていない景観計画について は、当該団体に連絡をして直接入手した。

次に、景観計画の内容を分析して、概念的な定義を用いた眺望景 観保全制度を位置づけている 85 団体・176 眺望地区（Fig. 10）を研 究対象として選定した注 ${ }^{11)}$ 。なお、眺望景観保全制度は市町村が運 用している事例が殆どであるため、市町村によるものを対象とした。

（2）調査・分析 1 : 概念的な定義を用いた眺望景観保全制度の類型 化と特徴の分析

調査・分析 1 は、調查対象である 85 団体・176 眺望地区における 眺望景観保全制度の内容を分析し、視対象、視点場、眺望地区、保 全基準の類型化を行うとともに、その特徵を把握するものである。

（3）調査・分析 2 : アンケート調査による概念的な定義を用いた眺 望景観保全制度の設定の理由と課題

調查・分析 2 は、団体に対するアンケート調查により、(1)概念的 な定義を用いた眺望景観保全制度の設定の理由、(2)概念的な定義を 用いた眺望景観保全制度の現状の問題を把握するものである。アン 
ケートは、電子メールによって平成 25 年 12 月 15 日から平成 28 年 9 月 8 日にかけて複数回に分けて行った。(1)と(2)の両方のアンケー トの回答を得た 76 団体を対象とし、回収率は 89.4\%（85 団体中 76 団体）であった。

(1)調査・分析 2-1：概念的な定義を用いた眺望景観保全制度の設定 の理由の分析

アンケート調査の内容は、a.視対象が概念型である理由、b.視点場 が概念型である理由、c. 眺望地区が概念型である理由、d. 保全基準 が概念型である理由、である。

(2)調査・分析 2-2: 概念的な定義を用いた眺望景観保全制度の現状 の問題の分析

アンケート調查の内容は、a.眺望景観保全のための定量的な数值基 準を持つ他の関連制度（風致地区等）の併用の有無、b.眺望景観を阻 害した事例の有無、c. 事前協議等において事業者に眺望景観について 説明する際の問題の有無、d.眺望景観保全の今後の展望、である。

\section{3.概念的な定義を用いた眺望景観保全制度の特徵}

\section{（1）概念的な定義を用いた眺望景観保全制度の類型化}

176 眺望地区の視対象、視点場、眺望地区、保全基準に関して類型 すると、Fig. 10 に示寸通りである。

なお、1つの眺望地区では、視対象、視点場、保全基準がそれぞれ

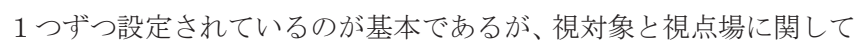
は、後述の通り、複数が設定されている場合があった。ただし、「具 体型」と「概念型」の両方が含まれているものは不在であった。

また、視対象の「概念型」は、視対象の数の特定が不可能であっ た場合（例えば景観計画に「山、河川、街並み等」とのみ記載があ り、具体的な数が決まっていない地区）の場合、1箇所としている。 同様に視点場の「概念型」も、視点場の数の特定が不可能であった 場合（例えば景観計画に「主要な地点から」とのみ記載があり、具 体的な数が決まっていない地区）は、1箇所としている。その結果、 176 地区における視対象は 186 籄所、視点場は 198 䇢所となった。

以下、4つの要素についてそれぞれ類型化するが、類型化の際に は該当する地区数を比較分析する。また視対象と視点場は 1 つの眺 望地区で複数のものが設定されている場合があることから細類型化 を行い、その際には該当する箇所数を比較分析する。

\section{（2）視対象に関する分析}

視対象は、「具体型」「概念型」「不在型」（以下、それぞれ「視 対象 (具)」、「視対象（概）」、「視対象（不）」と略すことがある）に 類型化することができ、さらにその属性によって自然物か人工物か、 ランドマーク型かパノラマ型かに細類型化することができ、両者の 組み合わせによって「自然・ランドマーク型」、「人工・ランドマー ク型」「自然・パノラマ型」「人工・パノラマ型」「混合・パノラ マ型」（以下、それぞれ「自然・ラ」、「人工・ラ」、「自然・パ」、「人 工・パ」「混合・パ」と略すことがある）とすることができた。

「視対象 (具)」とは、視対象の名称、位置、範囲が文章及び地図 上に明確に記載されているもの、「視対象（概）」とは、これらが明 確に記載されていないもの、「視対象（不)」とは、これらの記載が ないものである。「自然・ラ」とは、単体の山等によって構成された 眺望景観の範囲が限定的な視対象、「人工・ラ」とは、建築物等によ って構成された眺望景観の範囲が限定的な視対象、「自然・パ」とは、
山並み等によって構成された眺望景観の範囲が広域的な視対象、「人 工・パ」とは、建築物等によって構成された眺望景観の範囲が広域 的な視対象、「混合・パ」とは、建築物や山等が混合して構成された 眺望景観の範囲が広域的な視対象である。

\section{(1)視対象の類型化}

176 地区・186 箇所のうち、「視対象（具)」は 69 地区・76 箇所

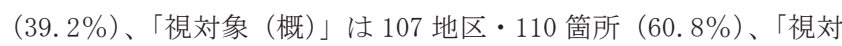
象（不)」は 0 地区・0 箇所（0\%）であった。(Fig. 1)

具体型 $(39.2 \%)$ と概念型（60.8\%）では、概念型が多かった。 また「視対象（不）」は不在であった。

\begin{tabular}{|c|c|}
\hline $\begin{array}{c}\text { No view target type } \\
\text { (視対象 (不)), } \\
\text { Odistricts, } 0.0 \%\end{array}$ & Vlew target \\
& concrete type \\
& (視対象 (具)), \\
& 69districts, \\
& 76 places,39.2\% \\
view target & \\
conceptual type & \\
(視対象 (概)), & \\
107districts, & \\
110places, $60.8 \%$ & \\
\hline
\end{tabular}

Fig.1 Classification of view target (視対象の類型)

\section{(2)視対象の細類型化}

「視対象 (具)」の 76 箇所を「自然・ラ」、「人工・ラ」、「自然・パ」、 「人工・パ」、混合・パ」に細類型化した結果、「自然・ラ」は 24

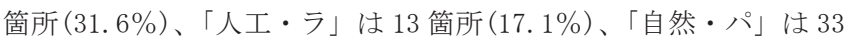

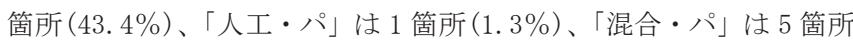
(6.6\%)であった。（Fig. 2)「視対象（概）」の110 箇所を同様に細類

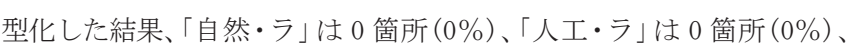

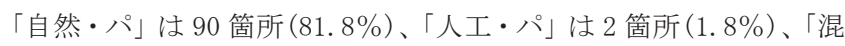
合・パ」は 18 箇所 (16.4\%)であった。(Fig. 2)

具体型では、ランドマーク型かパノラマ型かでみると、ランドマ ーク型は 37 箇所 (48.7\%)、パノラマ型は 39 箇所 (51.3\%) となり、 それぞれ半数程度と概ね同じ割合であった。人工物か自然物かでみ

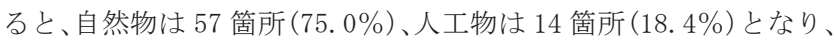
自然物が大変に多かった。

概念型では、ランドマーク型かパノラマ型かでみると、ランドマ ーク型は不在であり全てパノラマ型であった。人工物か自然物かで

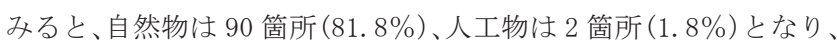
自然物が大変に多かった。

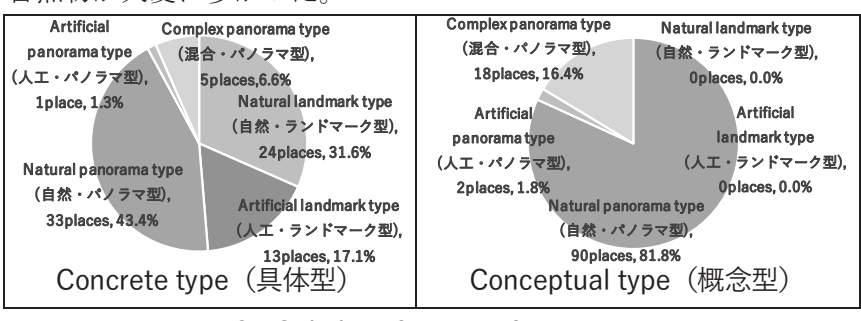

Fig.2 Subclassification of view target (視対象の細類型)

\section{(3)該当事例}

以上を踏まえて、具体型と概念型の一例として、それぞれ「人工・ ラ」と「自然・パ」、「自然・パ」を示すと Fig. 3 の通りである注 ${ }^{12)}$ 。 「視対象（具）：人工・ラ」の該当事例としては岐阜市があり ${ }^{1)}$ 、 視対象は岐阜城、三重塔、正法寺、善光寺、伊奈波神社であり、い 
ずれも人工物のランドマーク型であり、名称や位置等が文章及び図 上にて具体的に記載されている注 ${ }^{13)}$ 。「視対象 (具) : 自然・パ」に は柳井市が該当し 2)、視対象は三ヶ获、琴石山であり、いずれも自 然物のパノラマ型であり、同様に具体的に記載されている注 ${ }^{14)}$ 。「視 対象（概）：自然・パ」には椎葉村が該当し ${ }^{3)}$ 、視対象は景観拠点か ら眺望することのできる山並みとなっており、特定の山に限定され ているわけではなく、図上に明確に記載されていない注 ${ }^{15)}$ 。

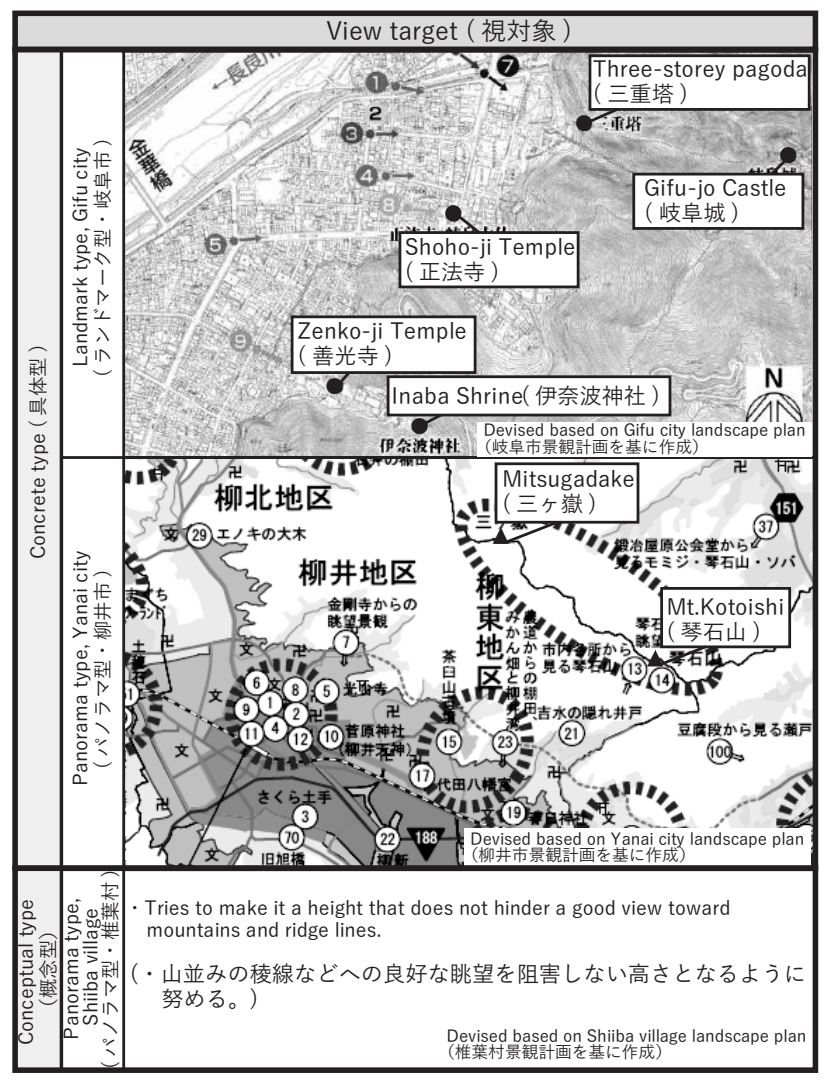

Fig.3 Instance of concrete or conceptual type regarding view target (視対象の一例)

\section{（3）視点場に関する分析}

視点場は、「具体型」、「概念型」「不在型」(以下、それぞれ「視 点場 (具)」、「視点場（概）」、「視点場（不）」と略すことがある）に 類型化することができ、さらに場の広がり状況によって「点型」、線 型」、「面型」に細類型化することができた。

「視点場 (具)」とは、視点場の名称、位置、範囲が文章及び地図 上に明確に記載されているもの、「視点場（概）」とは、これらが明 確に記載されていないもの、「視点場（不）」とは、これらの記載が ないものである。「点型」とは、展望台等において点状に指定される 視点場、「線型」とは、道路や歩道、河川敷等において線状に指定さ れる視点場、「面型」とは、城址や公園、市街地等において面状に指 定される視点場である。

\section{(1)視点場の類型化}

176 地区・198 箇所のうち、「視点場（具)」は 54 地区・107 箇所

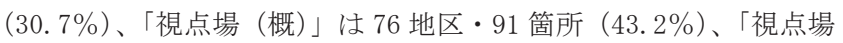
(不)」は 46 地区（26.1\%）であった。（Fig.4）
概念型（43.2\%）が最も高い割合を示し、具体型（30.7\%）と不 在型（26.1\%）が概ね同じ割合であった。

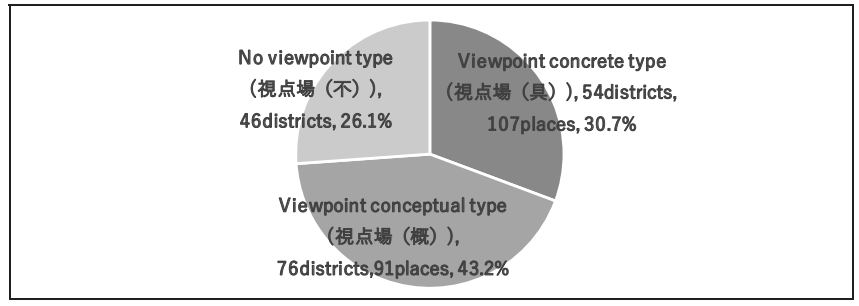

Fig.4 Classification of view point (視点場の類型)

\section{(2)視点場の細類型化}

「視点場 (具)」の 112 籄所を「点型」「線型」「面型」に細類型化 した結果、「点型」は 60 箇所 (53.6\%)、「線型」は 17 箇所 (15.2\%)、 「面型」は 35 箇所 (31.3\%) であった。（Fig. 5）「視点場（概）」の 91 箇所を同様に細類型化した結果、「点型」は 21 箇所 (23.1\%)、「線 型」は23箇所 (25.3\%)、「面型」は47箇所 (51.6\%)であった。(Fig. 5) 具体型では、点型」(53.6\%)の割合が最も高く、次いで、「面型」(31.3\%)、 「線型」(15.2\%) であった。概念型では、「面型」(51.6\%) の割合が 最も高く、次いで、「線型」(25.3\%)、「点型」(23.1\%) であった。

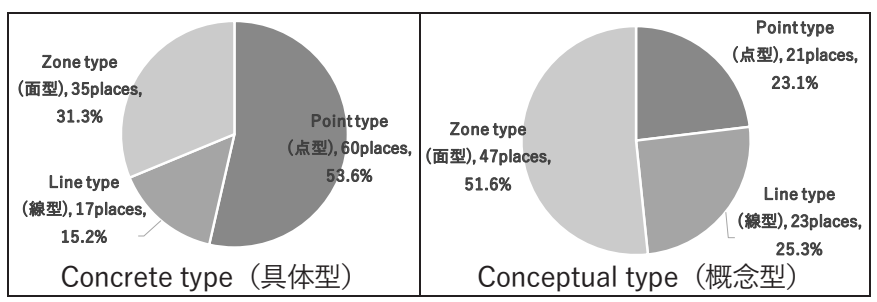

Fig.5 Subclassification of view point (視点場の細類型)

\section{(3)該当事例}

\section{以上を踏まえて、具体型と概念型の類型ごとの一例を示すと} Fig. 6 の通りである。「視点場（具）：点型」の該当事例としては岡 山市があり ${ }^{4)}$ 、視点場は延養亭と点型であり、名称や位置等が具体 的に記載されている注 ${ }^{16)}$ 。「視点場（具）：線型」には石岡市が該当 し ${ }^{5)}$ 、視点場はフルーツライン沿線と線型であり、同様に具体的に 記載されている注 17)。「視点場（具）：面型」には福井市が該当し ${ }^{6)}$ 、 視点場は養浩館庭園と面型であり、同様に具体的に記載されている

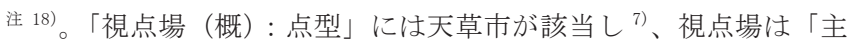
要な地点から」とのみ記載されており、具体的な名称、位置、範囲 が不在である注 19)。「視点場（概）：線型」には黒石市が該当し ${ }^{8)}$ 、 視点場は「浅瀬石川沿いや幹線道路沿いの眺めの良い場所」とされ ているものの、具体的な記載が不在である注 20 )。「視点場（概）：面 型」には西宮市が該当し ${ }^{9)}$ 、視点場は「平坦地から」とのみ記載さ れており、同様に具体的な記載が不在である注 21)。

\section{(4) 眺望地区に関する分析}

眺望地区は、「具体型」「概念型」「不在型」（以下、それぞれ「眺 望地区 (具)」、「眺望地区 (概)」、「眺望地区 (不)」と略すことがあ る）に類型化することができた。

「眺望地区（具)」とは、眺望地区において、地区の名称、位置、 


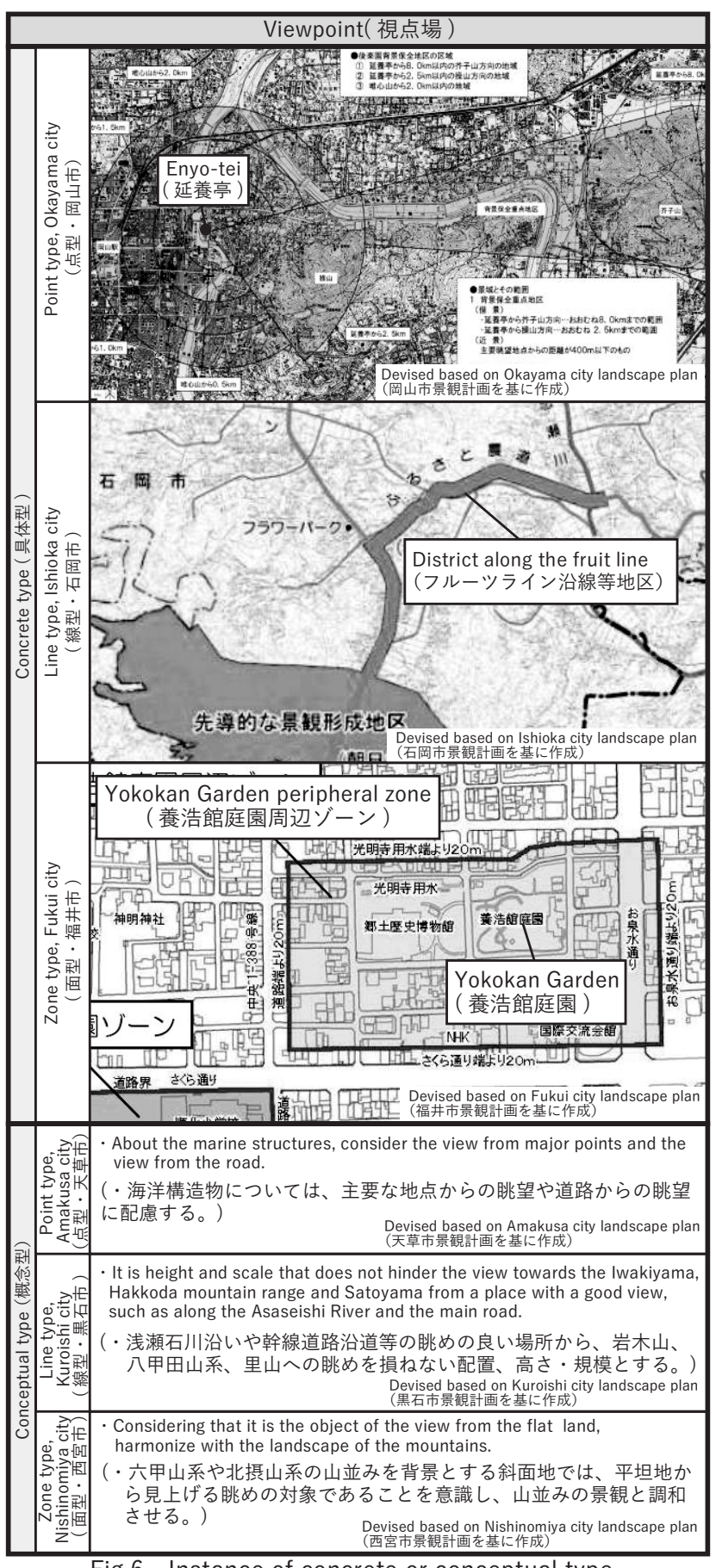

Fig.6 Instance of concrete or conceptual type regarding viewpoint （視点場の一例）

範囲が地図上に明確に記載されているもの、「眺望地区 (概)」とは、 これらが地図上に記載されているものの概略的な位置のみが示され、 その範囲の境界線が不明確であるもの、「眺望地区 (不)」とは、こ れらの記載がないものである。

\section{(1)眺望地区の類型化}

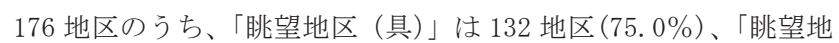

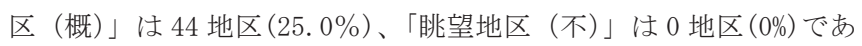
った。(Fig. 7)

具体型 $(75.0 \%)$ が最も高い割合を占め、次に概念型 $(25.0 \%)$ と なり、不在型に該当するものはなかった。

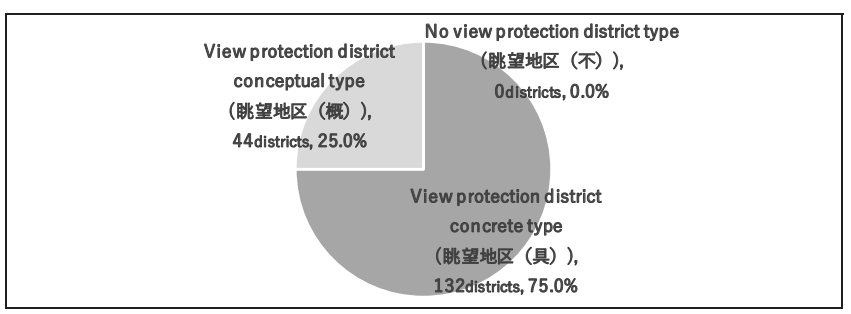

Fig.7 Classification of view protection district (眺望地区の類型)

\section{(2)該当事例}

以上を踏まえて、具体型と概念型の類型ごとの一例を示すと Fig. 8 の通りである。「眺望地区 (具)」の該当事例としては豊田市 があり ${ }^{10)}$ 、眺望地区は森林環境共生ゾーンであり、名称、位置、範 囲が地図上に明確に示されている注 22)。「眺望地区（概）」には昭和 村が該当し ${ }^{11)}$ 、眺望地区は高原エリアであり、名称は明確であるも のの地図上に示されている位置や範囲の境界が不明確である注 ${ }^{23)}$ 。

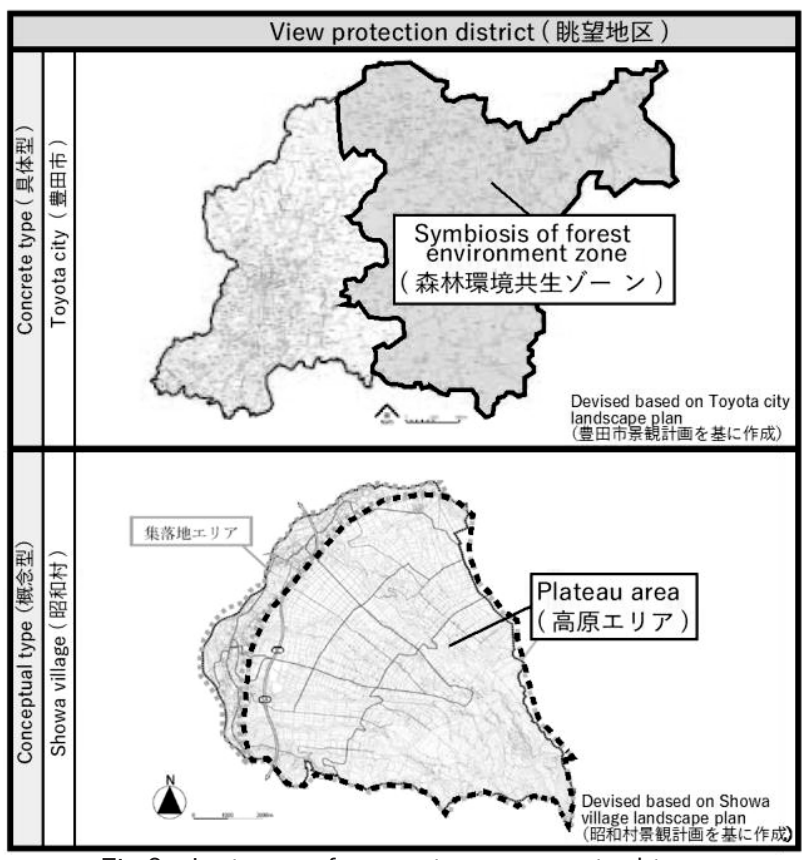

Fig.8 Instance of concrete or conceptual type regarding view protection district (眺望地区の一例)

(5) 保全基準に関する分析

保全基準は、具体型として「高さ基準（定量）」、概念型として「高 さ基準 (定性)」、不在型として「高さ基準なし」に類型化すること ができる。

「高さ基準 (定量)」とは、保全基準において、建築物・工作物等 の高さ基準が定量的な基準のもの、「高さ基準（定性）」とは、これ らが定性的な基準のもの、「高さ基準なし」とは、これらの記載がな いものである。

\section{(1)保全基準の類型化}

「高さ基準(定量)」は50 地区(28.4\%)、「高さ基準(定性)」は 103 地区 (58.5\%)、「高さ基準なし」は 23 地区 (13.1\%)であった。(Fig. 9) 概念型 $(58.5 \%)$ が最も高い割合を示し、次に具体型（28.4\%）、 不在型 $(13.1 \%$ ) であった。概念型と具体型を合計すると $86.9 \%$ と大 


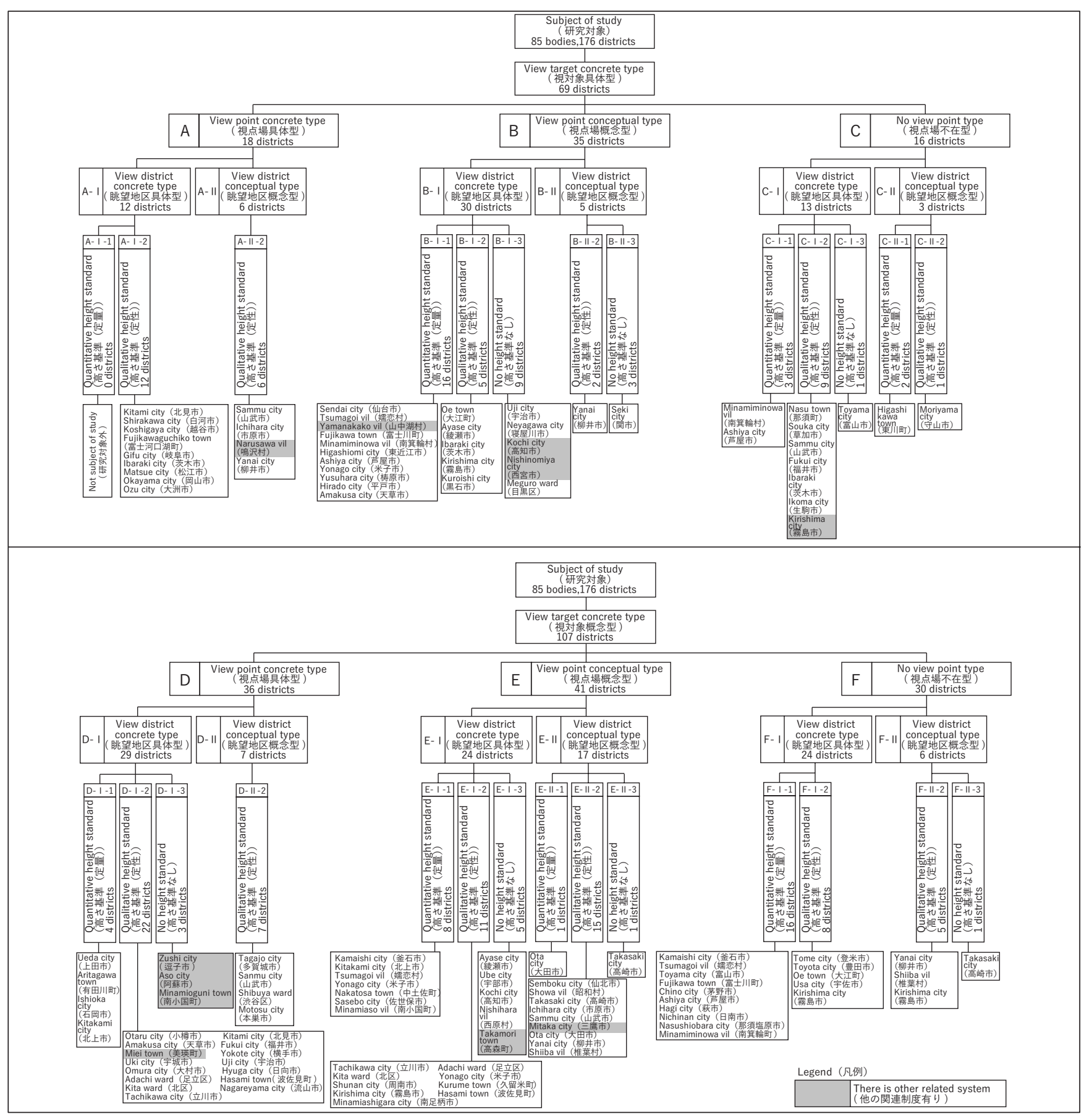

Fig.10 Classification chart of administrative system of view protection with conceptual definition （概念的な定義を用いた眺望景観保全制度の類型一覧）

ある事例として、岐阜市（金華区域）をFig. 11 に示す。

岐阜市景観計画では、良好な景観の形成の方針として、三重塔や 伊奈波神社、正法寺等の歴史的資源への眺めや金華山、長良川と一 体となったまちなみとが織りなす美しい眺望を保全、創出する方針 が記載されている注 26)。そして、視対象と視点場は、地図上に名称、 位置、範囲が示されている。また眺望地区も同様に地図上に範囲が 明確に示されている。しかしながら、保全基準は「金華山、岐阜城、 伊奈波神社、正法寺、三重塔への眺望景観と調和した高さとする」 等とされており、定性的である注 27)。

\section{(2) $E-I I-2$ の事例（椎葉村）}

視対象、視点場、眺望地区、保全基準の全てが概念型である事例
として、椎葉村（上椎葉地区）をFig. 12 に示す。

椎葉村景観計画では、良好な景観の形成の方針として、村の大部 分を占める九州山地の急峻な山並み景観は、道路・集落等の全ての 景観の背景となっており椎葉の景観の土台であること等が述べられ、 八重の山並みへの良好な眺望景観を守り・育てる方針が記載されて いる注 ${ }^{28)}$ 。しかしながら、視対象は拠点等から眺望することのでき る山並みとなっており、特定の山に限定されているわけではない。 また視点場は市街地景観拠点（上椎葉・岩屋戸・尾前地区）等と なっているが、各拠点の範囲は概略的に位置が地図上に示されてい るのみで明確に示されず、眺望地区も同様に明確には示されていな い。保全基準は、「山並みの稜線等への良好な眺望を阻害しないよう 


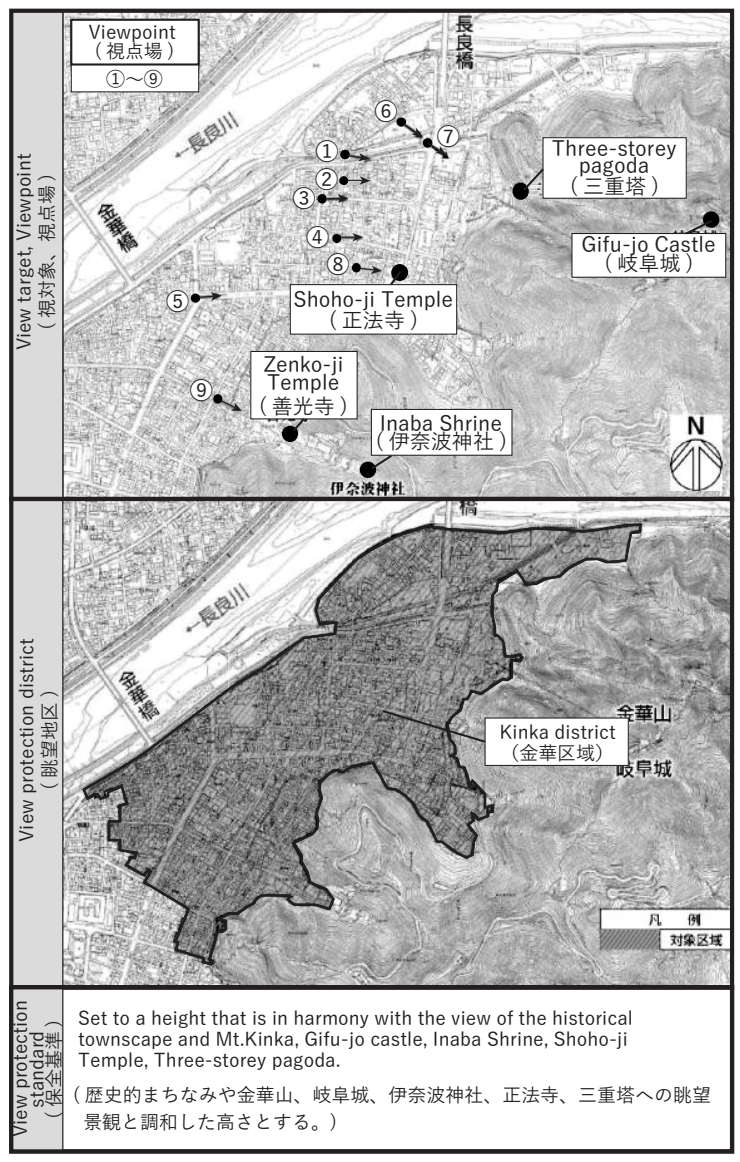

Fig.11 Case of A- I-2

Devised based on Gifu city landscape plan

(A-I-2「視対象・視点場・眺望地区 (具)、高さ基準 (定性)」 の事例(岐阜市景観計画を基に作成))

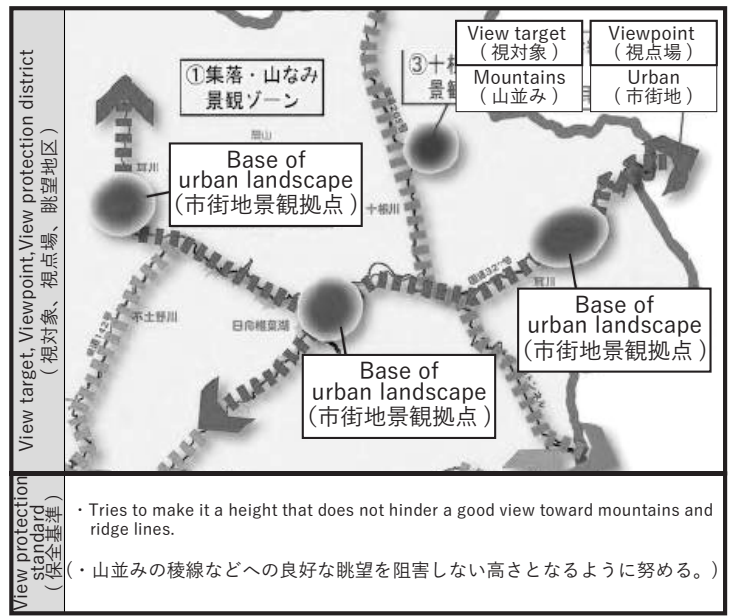

Fig.12 Case of E- II-2

Devised based on Shiiba village landscape plan

(E- II -2「視対象・視点場・眺望地区 (概)、高さ基準 (定性)」 の事例（椎葉村景観計画を基に作成））

な高さとなるように努める」等とされており、定性的である注 29)。

\section{(3)F- I -1 の事例（茅野市）}

視対象が概念型、視点場が不在型、眺望地区が具体型、保全基準 が具体型である事例として、茅野市(森林山地)をFig. 13 に示す ${ }^{14)}$

茅野市景観計画では、良好な景観の形成の方針として、市の魅力 を高めるために山地・山岳等への眺望は大きな魅力であるとし、こ
れらの眺望を確保する方針が記載されている注 ${ }^{30)}$ 。しかしながら、 視対象は山地・山岳であるものの明確な名称、位置、範囲の記載が なく、視点場も同様である。一方、眺望地区は地図上に明確に名称、 位置、範囲が示されているとともに、保全基準は「高さの最高限度 は、 $13 \mathrm{~m}$ とする」等とされており、定量的である注 311 。

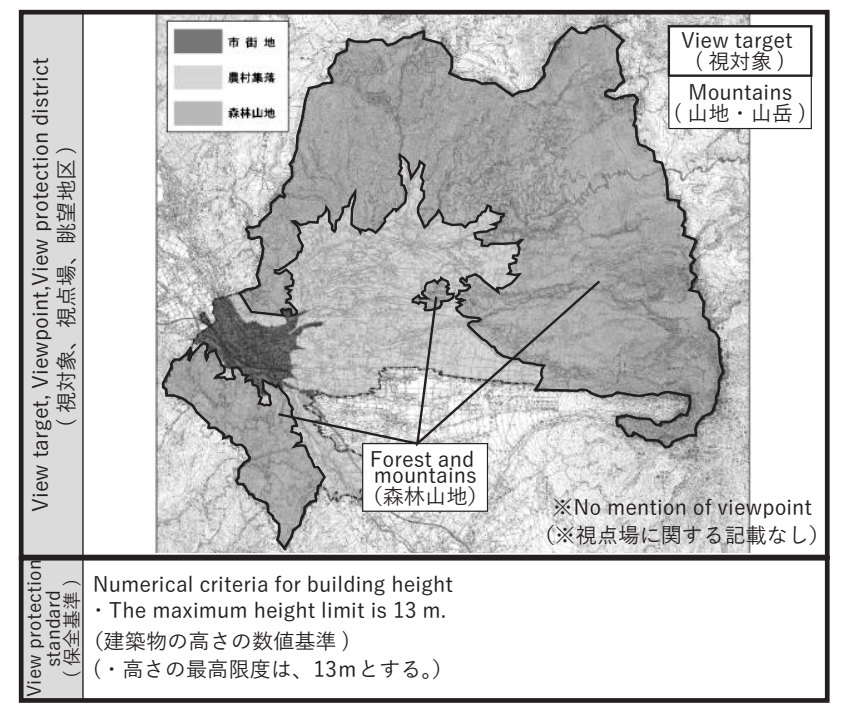

Fig.13 Case of F- I-1

Devised based on Chino city landscape plan

(F-I -1「視対象 (概) - 視点場(不) ・ 眺望地区(具)、高さ基準(定量)」 の事例（茅野市景観計画を基に作成））

\section{5. 概念的な定義を用いた眺望景観保全制度の設定の理由と現状の問}

題

団体に対するアンケート調查により、概念的な定義を用いた眺望 景観保全制度の設定の理由と現状の問題を把握する。

\section{(1) 視対象が概念型である理由}

回答が得られた「視対象（概）」（93 地区）における視対象が概念 型である主な理由は、以下の通りである。

「広がりのある眺望で、視対象の具体的な範囲の決定が難しいた め」(30 地区・32.3\%)、「視対象となりうる場所が多数あるため」(5 地区・5.4\%)、「自然的景観を視対象としているものの特にこれとい った視対象がないため」(5 地区・5.4\%)、「不明」(10地区・10.8\%)、 「未回答」(27 地区・29.0\%)、「その他」(16 地区・17.2\%)であった。

以上より、視対象が自然物を対象として広域である場合や多数あ る場合は、具体的な設定が難しいと判断していることがわかった。

\section{（2）視点場が概念型である理由}

回答が得られた「視点場 (概)」(62 地区) にお゙ける視点場が概念 型である主な理由は、以下の通りである。

「視点場となる地点が広域であるため」(14 地区・22.6\%)、「人々 が眺望できる場所は多くあり、視点場を特定することは困難である ため」(9 地区・14.5\%)、「視点場を定める必要性を感じていないた め」 $(2$ 地区・3.2\%)、「不明」 $(8$ 地区・12.9\%)、「未回答」（17 地 区・27.4\%)、「その他」(12 地区・19.4\%) であった。

以上より、視点場となる地点が広域であり境界の明確な範囲の設 定が難しい場合や、視点場となる地点が複数あり特定することが難 しい場合は、具体的な設定が難しいと判断していることがわかった。 


\section{（3）眺望地区が概念型である理由}

回答が得られた「眺望地区（概）」（44 地区）における眺望地区が 概念型である主な理由は、以下の通りである。

「現在は検討中であり、今後、具体的に設定していく予定である ため」(5地区・11.4\%)、「視対象、視点場が具体的に定められてい ないため」(4 地区・9.1\%)、「周囲の自然景観との調和を含めて広 域的なゾーンとして設定しており、詳細な設定を行う事はそぐわな いと考えているため」(3 地区・6. 8\%)、「不明」(8 地区・18.2\%)・「未 回答」（19 地区・43.2\%）、「その他」（5 地区・11.4\%）であった。 以上より、視対象と視点場が具体的に設定されていない場合や、 視対象が周囲の自然景観と調和するように広域的にゾーン指定して いるためにあえて眺望地区を明確にしない場合は、具体的な設定が 難しい（あるいはあえてしない）と判断していることがわかった。

また、第 3 章で述べた通り眺望地区は具体型が多いが、これを裏 付けるかのように、現在、概念型であっても、今後、具体的に設定 する予定の団体もあることがわかった。なお、不明・未回答が過半 数を占めていることから、現在の担当者が十分に設定の経緯を把握 していないと思われる団体が多いこともわかった。

\section{（4）保全基準が概念型である理由}

回答が得られた「高さ基準（定性）」（89 地区）における保全基準 が概念型である主な理由は、以下の通りである。

「眺望地区が広域又は多様な景観を有しており、一律の高さ設定 が困難であるため」（14 地区・15.7\%）、「届出制度において建築物・ 工作物の高さや規模、眺望景観への配慮した行為であるか確認して いるため」(3 地区・3.4\%)、「視点場又は視対象が決まっていない ため具体的な高さ制限をすることができないため」(3 地区・3.4\%)、 「不明」(13 地区・14.6\%)、「未回答」（44 地区・49.4\%）、「その他 (12 地区・13.5\%)」であった。

以上より、眺望地区が広域であり多様な景観を有している場合は、 一律の高さ設定が難しいと判断していることがわかった。そして視 点場と視対象が具体的に設定されていない場合は、眺望地区と同様 に具体的な設定が難しいと判断していることもわかった。

なお、保全基準と同様に不明・未回答が過半数を占めており、設 定の経緯を十分に把握していないと思われる団体が多いこともわか った。設定の経緯を把握しておくことは当然であり、景観計画を適 切に進行管理する上で改善する必要があると考えられる。

(5) 眺望景観保全のための定量的な基準を持つ他の関連制度の併用 の有無

回答が得られた 89 地区の中で、「定量的な基準を持つ他の関連制 度の併用あり」は、14 地区であった。具体的には、高度地区は 1 地 区 $(7.1 \%)$ 、風致地区は 1 地区 $(7.1 \%)$ 、地区計画は 2 地区 $(14.3 \%)$ 、 自然公園法による特別地域（国立公園）は 4 地区 (28.6\%)、条例（景 観条例やまちづくり条例）は 4 地区 $(28.6 \%)$ であった。2つの関連 制度を併用しているのは、高度地区と風致地区は 1 地区（7.1\%)、 風致地区と自然公園法による特別地域 (国定公園) は 1 地区 (7.1\%) であった。

以上より、定量的な基準を持つ他の関連制度としては、都市計画 法の高度地区や風致地区、自然公園法の特別地域を併用して運用し ていることがわかった。景観計画では定性的な基準を中心に設定し、 定量的な基準をもつ他の関連制度を併用して実行力の伴う眺望景観
保全に取り組むことは、1つの有効な方法と考えられる。

\section{（6）眺望景観を阻害した事例の有無}

回答が得られた地区（視対象：93 地区、視点場：62 地区、眺望地 区：44 地区、保全基準：89 地区）の中で、眺望景観の「阻害事例女 り」は、視対象、視点場、眺望地区はいずれも不在であり、保全基準 は 1 地区（1.1\%）であった。

「阻害事例あり」は保全基準に関するものであり、これは「太陽光 発電施設を設置する場合、公共空間・施設から望見できる場所に設 置する際には、植栽等による修景に努めると定めているが、大規模 な場合や主要道路に隣接する場合は、パネルやフェンスを設置する ことによって周辺の自然景観が阻害される事例がある」であった。

以上より、眺望景観を阻害した事例はあるものの、現状では殆ど 生じていないことがわかった。

\section{（7）事前協議等において事業者に説明する際の問題の有無}

回答が得られた地区（視対象：93 地区、視点場：62 地区、眺望地 区：44 地区、保全基準：89 地区）の中で、事前協議等において事業 者に説明する際の問題の発生について「問題あり」は、視対象は 4 地区 (4. 3\%)、視点場は 2 地区 (3. 2\%)、眺望地区は 4 地区 $(9.1 \%) 、$ 保全基準は 5 地区（5.6\%）であった。

「問題あり」の主な回答は、視対象と視点場については「事業者 から分かりにくいという意見があった」、眺望地区については「事業 者から範囲が分からないため、明確にして欲しいという意見があっ た」、保全基準については「行政担当者によって基準の判断が変わる 可能性が大いにある」、「具体的な数值基準がないために行政担当者 と事業者との見解が一致しなかった」等であった。

以上より、全体的に定義が明確でないために（当然のことながら） 分かりにくく、保全基準については行政担当者によって判断が変わ る可能性があり、また定量的な基準ではないために事業者と行政担 当者で判断が一致しない、等の問題があることがわかった。

\section{（8）眺望景観保全制度の今後の展望}

回答が得られた 76 団体における眺望景観保全制度の今後の展望 は、以下の通りである。

主な回答は、「今後、眺望地区を追加指定する」（9 団体・11.8\%）、 「今後、視点場を設定する」(5 団体・6.6\%)、「今後、景観計画を 見直していき眺望景観保全制度を検討寸る」（1 団体・1.3\%)、「特 に予定なし」(37 団体・48.7\%)、「未回答」（12 団体・15.8\%)、「その 他 $(12$ 地区・15.8\%)」であった。

以上より、今後の展望としては、現状では約半数が特に予定なし であるが、眺望地区の指定の追加や視点場の設定等について見直す 意向のある団体が一定数あることがわかった。

\section{6. おわりに}

本研究で明らかにした主な内容をまとめると、以下の通りである。 (1) 本研究においては、概念的な定義を用いた眺望景観保全制度を 運用している事例として 85 団体・176 眺望地区を確認し、研究対象 として選定したが、まず該当事例が多いことがわかった。

（2）眺望景観保全制度を構成している視対象、視点場、眺望地区、 保全基準を類型した結果、概念型になる傾向が高いのは、視対象と 保全基準であることがわかった。視対象は、自然物を対象としたパ ノラマ型である場合は概念的になる傾向が高く、保全基準は（視対 
象等が概念的かに関わらず）定性的な基準が多いことがわかった。 また具体型でも概念型でもなく不在型となる場合があるのは、視点 場と保全基準であり、これは何も記載がないために概念型以上に眺 望景観の保全を担保することが出来なくなることが危惧される。

（3）団体へのアンケート調查結果より、概念的な定義を用いた主な 理由としては、視対象は自然物を対象としたパノラマ型の広域景観 である場合は具体的な設定が難しいこと、視点場は対象となる地点 が広域である場合や複数ある場合は特定することが難しいこと、眺 望地区は視対象と視点場が具体的でない場合は同様に具体的に設定 しにくいこと、保全基準は眺望地区が広域であり多様な景観を有し ている場合は一律の高さ基準を設定しにくいこと、等があげられた。

また、概念的な定義を用いた眺望景観保全制度の設定の経緯を十 分に把握していないと思われる団体が多いこともわかり、これは景 観計画を適切に進行管理する上で改善する必要があると考えられる。

（4）眺望景観を阻害した事例は、現状では殆ど生じていないため、 大きな問題にはなっていないと考えられる。しかしながら、事前協 議等における事業者への説明の際の問題として、定義が明確になっ ていないために分かりにくく、定量的な基準ではないために事業者 と行政担当者で判断が一致しない、等があげられていることから、 将来的には眺望景観を阻害する事例が増えることが危惧される。

（5）今後の展望としては、眺望景観保全制度を見直す意向のある団 体も一定数あることから、必要に応じて適切な見直しを行い、不在 型や概念型から具体型に移行することが望ましいと考えられる。

（6）以上を踏まえて、最後に具体型への移行について概観したい。 まず視対象と視点場を具体型として明確にすることが必要である。 前述の通り、両者が概念型として設定されると、眺望地区と保全基 準も概念型になる傾向が高いためである。そしてその次は、眺望地 区と保全基準も同様に具体型にすることが必要である。(本研究では 詳細に言及しないものの) 具体型な定義を持つ眺望景観保全制度を 運用している団体では、4つの構成要素は何れも明確に定義されて 運用されていることから、先進事例（例えば京都市）を参照して検 討することにより、現状の問題を改善することは可能と考えられる。

また、景観計画では定性的な基準を中心に設定していても、定量 的な基準を持つ他の関連制度を併用して運用している団体もあり、 両者を併用して取り組むことも 1 つの有効な方法と考えられる。

今後の課題は、具体的な定義を持つ眺望景観保全制度の実態も明 らかにして、眺望景観保全制度の全体像を考察することである。

\section{謝辞}

本研究におけるアンケート調查にご協力頂いた景観行政団体の担 当者の皆様、分析にご協力頂いた長坂昌紀氏にお礼を申し上げます。

\section{参考文献}

1) Gifu city:Gifu city landscape plan, 2009 岐阜市: 岐阜市景観計画, 2009

2) Yanai city:Yanai city landscape plan, 2012 柳井市: 柳井市景観計画, 2012

3) Shiiba village:Shiiba village landscape plan, 2012 椎葉村: 椎葉村景観計画, 2012

4) Okayama city:0kayama city landscape plan, 2007 岡山市: 岡山市景観計画, 2007

5) Ishioka city: Ishioka city landscape plan, 2012 石岡市: 石岡市景観計画, 2012

6) Fukui city:Fukui city landscape plan, 2008 福井市: 福井市景観計画, 2008

7) Amakusa city:Amakusa city landscape plan, 2009
天草市: 天草市景観計画, 2009

8) Kuroishi city:Kuroishi city landscape plan, 2015 黒石市:黒石市景観計画, 2015

9) Nishinomiya city:Nishinomiya city landscape plan, 2009 西宮市: 西宮市景観計画, 2009

10) Toyota city: Toyota city landscape plan, 2008 豊田市: 豊田市景観計画, 2008

11) Showa village: Showa village landscape plan, 2015 昭和村 : 昭和村景観計画, 2015

12) Hirado city:Hirado city landscape plan, 2009 平戸市:平戸市景観計画, 2009

13) Otaru city:0taru city landscape plan, 2009 小樽市: 小樽市景観計画, 2009

14) Chino city: Chino city landscape plan, 2010 茅野市: 茅野市景観計画, 2010

注

注 1) 日本らしく美しい景観づくりに関する懇談会：「日本らしい美しい景観 づくりに関する懇談会」報告書, 国土交通省, 2015

注 2) 京都市眺望景観創生条例 http://www.city.kyoto.lg.jp/, (参照 2016-11-1)

注3）日本建築学会編:成果景観法10年の運用,『景観計画の実践』,pp. 153-154, 森北出版, 2017

注4）景観法制研究会編: 景観法の概要, 『逐条解説 景観法』, pp. 9-10, 国土 交通省都市・地域整備局都市計画課監修,ぎょうせい, 2004

注5) 国の景観法運用指針では、例えば、景観計画区域については、計画図に 表示することとされ、通常は明示的に表示できる縮尺の図面を使用する ことが望ましく、特に景観計画区域の境界付近等では、土地に関し権利 を有する者が容易に判断できるように、原則として縮尺 $1 / 2500$ 程度の画 図と寸べきであること、景観形成基準は、法第16条第3項の勧告又は変更 命令の基準となるものであり、可能な限り客観的な基準とすることが望 ましく、特に同項の特定届出対象行為に係る景観形成基準については、 少なくとも例示を示寸等、明示的な基準とすべきであるとしている。

注 6) 坂和章平:眺望・景観をめぐる法と政策, 民事法研究会, pp. 88-89, 2012

注 7) 岡村祐:視点場の指定と景観誘導範囲の指定に着目した眺望景観保全計 画の類型化 我が国における眺望景観保全の計画理論に関する研究 (その 1), 日本建築学会計画系論文集, Vol. 74, pp. 1795-1804, 2009

注 8) 川崎修良:眺望景観保全を目的とした建築高さ制限の手法についての研 究 景観法施行後の各景観行政団体の事例に着目して,日本建築学会 計画系論文集, Vol. 75, pp. 2643-2648, 2010

注 9) 大澤昭彦:高さ制限とまちづくり，学芸出版社, 2014

注 10) 景観行政団体と景観計画の策定状況は国土交通省ホームページを参照。 http://www.mlit.go.jp/toshi/townscape/toshi_townscape_tk_000026. html, (参照 2016-11-1)

注11）「眺望景観保全制度」に該当するかどうかは、景観計画の中に眺望を保 全する旨の記載があるかどうかを判断基準とし、記載がある場合は、 視対象、視点場、眺望地区、保全基準等が記載されているかどうかを 判断基準としている。また「眺望景観」の用語は必ずしも用いられて はおらず、「眺望」や「眺め」が多くみられた「「視対象」や「視点 場」も同様であり、眺める対象や場所の名称の記載が多く、また視点 場は「眺望点」や「ビューポイント」がみられた。眺望地区は景観重 点地区や景観形成地域等が、保全基準は全て景観形成基準が用いられ ていた。なお、眺望地区が市区町村全域の地区である場合は、4つの構 成要素の全てが不明確であり、実行力のある眺望景観保全制度ではな いと考えられることから対象外としている。

注12)第 3 章で掲載している該当事例は、概念型を理解しや寸く寸るために、 景観行政団体のホームページで公開されている景観計画の中で、でき るだけ高画質な図面が使用され、判読しやすいものを選出している。

注 13) 参考文献 1) , p. 31

注 14) 参考文献 2), p. 23

注 15) 参考文献 3) , p. 18

注 16) 参考文献 4), p. 14

注 17) 参考文献 5）, p. 26

注 18) 参考文献 6) , p. 6

注 19) 参考文献 7），p. 44

注 20) 参考文献 8), p. 7

注 21) 参考文献 9) , p. 18

注 22) 参考文献 10）, p. 48

注 23) 参考文献 11）, p. 1

注 24）参考文献 12）, p. 63

注 25) 参考文献 13）,p. 64

注 26) 参考文献 1）, p. 27

注 27）参考文献 1）,p. 29

注 28) 参考文献 3）, pp. 9-15

注 29) 参考文献 3) , p. 23

注 30）参考文献 14）,p. 14

注 31）参考文献 14）,p. 22 


\title{
A STUDY ON THE ADMINISTRATIVE SYSTEM OF VIEW PROTECTION WITH CONCEPTUAL DEFINITION OF LANDSCAPE PLAN
}

\author{
Satoshi ASANO *1, Takuya UEDA*2 and Yoshihiko MIZUNO *3 \\ ${ }^{*}$ Assoc. Prof., Graduate School of Eng., Mie Univ., Dr.Eng. \\ ${ }^{* 2}$ Grad. Student, Mie Univ. \\ ${ }^{*}$ Okazaki City Government, M.Eng.
}

The purpose of this study is to clarify the characteristic, the reason for institution and the issue of view protection with conceptual definition. The authors analyzed the landscape plan of 664 organizations (local governments) that instituted the landscape plan and extracted system of view protection with conceptual definition. As a result, 176 view protection districts from 85 organizations were selected as research subjects.

The main contents clarified in this research are as follows.

1) The system of view protection with conceptual definition are operating for 176 districts from 85 organizations, and there are many relevant cases.

2) Four components of the system of view protection; view target, viewpoint, view protection district, view protection standard are classified into concrete type, conceptual type and no type.

- The high tendency to become conceptual type is view target and view protection standard.

- View target tends to become conceptual when it is a panoramic type for natural objects, and the view protection standard tends to be a qualitative.

- Viewpoint and view protection standard are sometimes no type, therefore it is deeply concerned about that no type cannot protect the view than conceptual type.

3) Through analysis of the questionnaire survey, it is clarified the main reason operated the system of view protection with conceptual definition are following.

- View target and viewpoint are included the wide area, it is difficult to decide a range concretely. View target and viewpoint are designated with conceptual definition, it is also difficult to decide view district concretely. And view protection standard are difficult to set the uniform height standards when the view protection district is a wide area and has various landscapes.

- Many organizations did not adequately record the process of instituting the system of view protection based on a conceptual definition. This is an issue in properly managing landscape planning.

4) It is considered there is no serious obstruction of view fortunately. However, some issues are pointed out when administrative officer explains the development company. For example, as it is hard to understand concretely four components of the system of view protection with conceptual definition, a judgment between administrative officer and the development company is sometimes different. Therefore, it could go wrong that view might be obstructed in the future.

5) It is desirable to change the conceptual type and no type to the concrete type regarding the system of view protection for solving these issues in the future.

6) The future task is to clarify the actual state of system of view protection with concrete definition and to consider the whole perspective. 